\title{
PELATIHAN PEMBUATAN POP UP BOOK SEBAGAI MEDIA PEMBELAJARAN SAINS BAGI GURU TAMAN KANAK-KANAK
}

\author{
Oleh: \\ Noly Shofiyah ${ }^{1}$, Fitri Eka Wulandari \\ 1,2Universitas Muhammadiyah Sidoarjo \\ 1nolyshofiyah@umsida.ac.id
}

\begin{abstract}
Abstrak
Tujuan dari kegiatan ini adalah: (1) Memberikan pengetahuan teoritis kepada guru-guru di TK Dharmawanita, Kedung Banteng dan TK KB Permata Hati Aisyiyah, Tanggulangin, Sidoarjo tentang pembelajaran sains di TK dan (2) Melatih guru-guru di TK Dharmawanita, Kedung Banteng dan TK KB Permata Hati Aisyiyah membuat pop up book sebagai alternative media pembelajaran sains di TK. Untuk mencapai tujuan tersebut, maka dilakukan dua kegiatan yang dilaksanakan selama dua hari yaitu: (1) pelatihan tentang pembelajarn sains (2) workshop pembuatan media pop up book. Metode yang digunakan dalam kegiatan ini adalah ceramah, tanya jawab, diskusi, demonstrasi dan pemberian tugas. Hasil dari kegiatan ini adalah meningkatnya pemahaman guru tentang pembelajaran sains di TK yang ditunjukkan dengan peningkatan nilai post-test dibandingkan dengan nilai pre-test. Selain itu, guru juga mampu membuat media pembelajarn sains yang berupa pop up book.
\end{abstract}

Kata Kunci: Pembelajaran Sains TK, Media, Pop Up Book

\begin{abstract}
The aims of this study were: (1) to provide theoretical knowledge of kindergarten science to teachers in Dharmawanita Kindergarten, Kedung Banteng and Permata Hati Aisyiyah Kindergarten, Tanggulangin, Sidoarjo and (2) to train the teachers make a pop up book as an alternative media of learning science in kindergarten. To achieve these objectives, two activities were carried out for two days, namely: (1) training on learning science in kindergarten (2) workshop making a pop-up book. The methods had been used in this activity were lectures, questions and answers, discussions, demonstrations and assignments. The result showed that the teacher's understanding about science learning in kindergarten increased. In addition, teachers were also able to create a learning media science in the form of pop up book
\end{abstract}

Keywords: Kindergarten Science Learning, Media, Pop Up Book

\section{PENDAHULUAN}

Sains terdiri dari produk dan proses. Sains sebagai produk merupakan pengetahuan yang terorganisir dengan baik mengenai dunia fisik alami, sedangkan sains sebagai proses meliputi kegiatan menelusuri, mengamati dan melakukan percobaan. $\mathrm{Di}$ taman kanak-kanak (TK), pembelajaran sains bertujuan untuk membantu anak didik memahami konsep sains dan penerapannya dalam kehidupan sehari-hari, antara lain berkaitan dengan gejala alam, masalah lingkungan maupun teknologi sederhana. Karena pembelajaran sains tidak tercantum di dalam kurikulum TK, bukan berarti bahwa sains tidak ada di TK. Sains di TK tetap ada dan terintegrasi dengan bidang lainnya di setiap tema. Sains jika dikenalkan dengan benar pada anak TK akan mengembangkan kemampuan berpikir logis anak secara bertahap.

Pengembangan pembelajaran sains pada anak usia dini menurut Leeper (Nugroho, 2008) bertujuan agar:

1. Anak memiliki kemampuan memecahkan masalah yang dihadapinya melalui penggunaan metode sains, sehingga anak-anak terbantu dan menjadi terampil dalam menyelesaikan berbagai hal yang dihadapinya.

2. Anak memiliki sikap-sikap ilmiah, misalkan tidak cepat-cepat dalam mengambil keputusan, dapat melihat segala sesuatu dari berbagai sudut pandang, berhati-hati terhadap informasiinformasi yang diterimanya serta bersifat terbuka.

3. Anak mendapatkan pengetahuan dan informasi ilmiah (yang lebih percaya dan baik), maksudnya adalah segala 
informasi yang diperoleh anak berdasarkan standar keilmuan yang semestinya, karena informasi yang disajikan merupakan hasil temuan dan rumusan yang obyektif serta sesuai kaidah-kaidah keilmuan yang menaunginya.

4. Anak-anak menjadi lebih berminat dan tertarik untuk menghayati sains yang berada dan ditemukan di lingkungan dan alam sekitarnya.

Uraian di atas menjelaskan bahwa pengenalan sains pada anak TK dianggap sangat penting. Namun jika dilihat pada kenyataanya, minat anak-anak terhadap pengetahuan sains bersifat fluaktuatif, kadang tinggi dan kadang rendah. Salah satu penyebabnya adalah anak-anak mengalami kesulitan dalam memahami sains.

Oleh karena itu, pengetahuan sains hendaknya diperkenalkan pada anak-anak sejak dini sehingga anak-anak tidak merasa takut mempelajari sains. Salah satu upaya yang bisa dilakukan guru supaya dalam mengajarkan sains pada anak-anak lebih menarik adalah dengan menggunakan media pembelajaran yang dapat menarik perhatian anak dan memancing keinginan anak untuk belajar dengan cara yang lebih menyenangkan. Fungsi media pembelajaran bukan hanya sebagai sarana untuk membuat pembelajaran yang menyenangkan, tetapi juga membantu anak memahami konsep sains.

Salah satu alternatif media pembelajaran yang dengan potensimya dapat menarik perhatian anak adalah Media pop up. Media pop up adalah media yang berbentuk tiga dimensi dan bersifat interaktif. Dengan menggunakan media tersebut, guru dapat memberikan materi sains pada anak dengan cara yang berbeda. Media pop up dapat membangkitkan motivasi anak dalam belajar, karena dalam penggunaannya dapat disertai dengan cerita yang menarik yang dekat dengan lingkungan mereka. Penggunaan ilustrasi, warna, dan tipografi disesuaikan dengan kesukaan anak sehingga anak merasa lebih akrab dengan karakter-karakter yang dibuat, (Safitri, 2014).

Mitra dalam kegiatan ini adalah guru-guru Taman kanak-kanak di TK Dharmawanita, Kedung Banteng, Tanggualangin, Sidoarjo yang berjumlah 3 orang. Sebagian besar, mereka sudah berpendidikan $\mathrm{S} 1$ namun tidal linear dengan profesi mereka. Artinya, guruguru tersebut mengajar berdasarkan pengalaman dan belum memiliki kemampuan profesional untuk melaksanakan tugasnya. Dalam pengajarannya, guru masih sering menggunakan pendekatan konvensional, termasuk dalam pembelajaran sains. Guru jarang membuat lembar kerja siswa sendiri dan masih banyak menggunakan lembar kerja siswa yang dibeli dari toko-toko buku. Kurang kreatifnya guru meneyebabkan mereka kesulitan dalam mengembangkan mediapemeblajaran sendiri.

Hal senada juga terjadi pada guru-guru TK KB Permata Hati Aisyiyah, Sidoarjo yang berjumlah 4 orang yang juga belum berpendidikan S1 PG-PAUD. Hampir semua guru-guru tersebut menggunakan media dan lembar kerja siswa yang di jual di toko-toko, karena mereka kesulitan dalam mengembangkannya. Suasana pembelajaran di TK menjadi seperti pembelajaran di SD. Oleh karena itu, perlu adanya peningkatan mutu layanan pendidikan pada level taman kanak-kanak.

Berdasarkan uraian di atas, maka perlu dilaksanakan suatu pelatihan tentang pembelajaran sains pada level anak usia dini dan pelatihan pembuatan media POP UP $B O O K$ kepada guru TK agar mereka lebih kreatif lagi dalam pengajaran dan pembuatan media sains.

\section{METODE PELAKSANAAN}

Metode pelaksanaan IbM bagi Guru Taman Kanak-Kanak melalui Pelatihan Pembuatan Pop Up Book sebagai Media Pembelajaran Sains meliputi tiga tahap.

1. Tahap persiapan

Pada tahap persiapan dilakukan koordinasi dengan tim pelaksana IbM, pihak sekolah untuk mensosialisasikan program-program IbM.

\section{Tahap pelaksanaan}

Tahap pelaksanaan IbM ini adalah sebagai berikut: (1) memberikan pelatihan dan workshop bagi guru tentang pengembangan strategi pembelajaran sains di TK, (2) memberikan pelatihan bagi guru tentang pembuatan media pembelajaran sains yang berupa pop up book, dan (3) mengembangkan media pembelajaran sains di TK yang berbentuk pop up book dengan tema sains tertentu.

3. Tahap evaluasi dan monitoring

Kegiatan yang dilaksanakan adalah (1) Monitoring, dan evaluasi pelaksanaan kegiatan IbM. Monitoring dan evaluasi terhadap pelaksanaan program kegiatan IbM yang dilakukan berupa review rencana 
kegiatan, proses berupa kesesuaian mekanisme kegiatan yang dilakukan dengan yang direncanakan termasuk penggunaan sumber daya dan alokasi waktu serta tingkat keterlibatan partisipan dan stakeholder, (2) Pelaporan, evaluasi, refleksi, dan rekomendasi hasil program IbM.

\section{HASIL DAN PEMBAHASAN}

Kegiatan pengabdian ini telah dilaksanakan pada hari Selasa dan Rabu, 24 dan 25 Januari 2017, yang bertempat di TK
Dharmawanita, Kedung Banteng, Tanggualangin, Sidoarjo. Keberhasilan dari kegiatan ini dapat dilihat dari indikator : 1) meningkatnya pengetahuan guru tentang pembelajaran sains di TK 2) mampu membuat media pembelajaran sains sendiri yang berupa pop up book.

Hasil dari kegiatan Ipteks Bagi Masyarakat ini adalah :

1. Peningkatan kemampuan guru yang ditunjukkan dengan peningkatan skor antara skor pre-test dan post- test.

Tabel 1. Nilai Pre-test dan Post-test Pembelajaran Sains di TK

\begin{tabular}{|c|c|c|c|}
\hline Subjek & Guru & Pre-test & Posttest \\
\hline \multirow{4}{*}{$\begin{array}{l}\text { TK Permata Hati } \\
\text { Aisyiyah, } \\
\text { Kalidawir, } \\
\text { Tanggulangin } \\
\text { Sidoario }\end{array}$} & Guru 1 & 65 & 80 \\
\hline & Guru 2 & 65 & 85 \\
\hline & Guru 3 & 55 & 75 \\
\hline & Guru 3 & 53 & 74 \\
\hline \multirow{3}{*}{$\begin{array}{l}\text { TK } \\
\text { Dharmawanita, } \\
\text { Kedungbanteng, } \\
\text { Tanggulangin, } \\
\text { Sidoarjo. }\end{array}$} & Guru 1 & 55 & 85 \\
\hline & Guru 2 & 60 & 80 \\
\hline & Guru 3 & 50 & 80 \\
\hline Rata-rata & & 58 & 81 \\
\hline
\end{tabular}

Tabel 1 menunjukan bahwa terdapat peningkatan pemahaman guru tentang pembelajaran sains di taman kanak-kanak setelah dilakukan pelatihan dan workshop. Pada saat pelatihan, guru-guru TK Dharmawanita, Kedungbanteng, dan TK KB Permata Hati Aisyiyah, Kalidawer, Tanggulangin, Sidoarjo juga berpartisipasi aktif yang ditunjukkan dengan respon guru terhadap tentor dalam bentuk bertanya, menanggapi dan memberikan contoh penerapan konsep sains dalam pembelajaran IPA di TK.

Konsep pembelajaran IPA yang diberikan pada saat pelatihan, diharapkan dapat diterapkan oleh guru dalam setiap pembelajarannya. Konsep tersebut bisa dijadikan landasan oleh guru dalam mengembangkan metode dan menyusun skenario pembelajaran. Menurut Nugroho (2008), Pembelajaran sains pada anak usia dini sebaiknya berkaitan dengan kegiatan eksplorasi yang memungkinkan anak untuk menyelidiki berbagai benda yang ada di sekitarnya. Objek dan fenomena yang menarik dapat dihadirkan ke dalam kelas. Sebagai contoh, guru menghadirkan anak ayam dengan induknya, atau dengan memperlihatkan kepompong yang akan menjadi kupu-kupu. Anak akan merasa tertarik, karena secara nyata mereka dapat memperhatikan perilaku dan perubahan binatang tersebut. Selain itu, anak juga dapat diajak untuk melakukan eksperimen sederhana. Misalnya telur ajaib, yaitu telur ayam yang dimasukkan ke dalam larutan garam dengan kosentrasi yang berbeda. Dengan telur yang sama, telur tersebut akan mengalami keadaan yang berbeda yaitu mengapung, melayang dan tenggelam. Melalui kegiatan eksplorasi, hampir semua panca indera anak akan digunakan untuk penyelidikan.

2. Guru mampu membuat media pembelajaran sains yang berupa pop up book secara mandiri.

Pada hari kedua pelatihan, guru dilatih untuk membuat media sains berupa pop up book dengan tema yang ditentuka sendiri oleh guru. Melalui pelatihan ini guru akhirnya dapat membuat sendiri media pembelajaran sains dengan memanfaatkan gambar-gambar dari majalah bekas atau menggambar sendiri objek yang akan digunakan dalam membuat pop up book.

Menurut Piaget perkembangan kognitif anak usia TK yaitu 5-6 tahun merupakan masa transisi dari Pra-operasional ke fase 
Konkret operasional. Cara berpikir konkret berpijak pada pengalaman akan benda-benda konkret, bukan berdasarkan pengetahuan atau konsep-konsep abstrak (Wolfinger, 1994). Anak-anak mulai dapat memahami beberapa konsep sains yang bersifat abstrak, tetapi dengan contoh-contoh yang kongkrit. Pada tahap ini anak belajar terbaik melalui praktek langsung atau kehadiran bendabenda. Obyek permanen (object permanency) sudah mulai berkembang dimana anak dapat berlajar mengingat benda-benda, jumlah dan ciri-cirinya meskipun bendanya sudah tidak berada dihadapannya. Anak tertarik pada buku-buku yang ada kaitannya dengan aktivitas praktek sains dengan beberapa ilustrasi-ilustrasi berupa gambar. Oleh karena itu, kemampuan guru dalam membuat media sangat membantu dalam mengembangkan cara berfikir saintifik anak di TK.

\section{SIMPULAN DAN SARAN}

Berdasarkan uraian-uraian sebelumnya, maka dapat disimpulkan: (1) pelatihan pembelajaran sains di TK dan workshop pembuatan media pop up book di TK Dharmawanita, Kedungbanteng, dan TK KB Permata Hati Aisyiyah, Kalidawer, Tanggulangin, Sidoarjo berjalan dengan baik. (2) pemahaman guru tentang pembelajaran sains di TK meningkat. (3) guru mampu membuat media pembelajaran sains secara mandiri dengan menghasilkan pop up book.

Kedepannya, diperlukan suatu pelatihan yang lebih mendalam untuk pembuatan media pop up book. Sehingga guru tidak hanya mampu membuat media pop up book dengan teknik sederhana tetapi juga mampu membuat media pop up book dengan teknik yang lain.

\section{DAFTAR PUSTAKA}

Dzuanda. (2009). Perancangan Buku Narasi Anak Pop Up Tokoh-tokoh Wayang Berseri, Seri Gatoto Kaca. Skripsi ini tidak diterbitkan. Surabaya: Desain Komunikasi Visual/ Teknik Sipil dan Perencanaan/ ITS.

Nugroho.A., (2008). Pengembangan Pembelajaran Sains Pada Anak Usia Dini. Bandung

Wolfinger, D.M. (1994). Science and Mathematics in Early Childhood Education. New York: Harper Collins College Publishe.

Safitri, N. N. (2014). Pengembangan Media Pop Up Book untuk Keterampilan Menulis Narasi Siswa Tunarungu Kelas IV. Jurnal Pendidikan Khusus, $4(1)$. 